\title{
Pengaruh Likuiditas, Leverage, dan Aktivitas terhadap Rentabilitas pada Perusahaan Otomotif yang Terdaftar di Bursa Efek Indonesia Periode 2011-2017

\author{
Angel Garcia \\ Universitas Prima Indonesia \\ Medan,Indonesia \\ Calvin Adrian \\ Universitas Prima Indonesia \\ Medan,Indonesia \\ calvin.adrian97@gmail.com
} \\ Angelgarcia0812@yahoo.com

\author{
Yuni Siawira \\ Universitas Prima \\ Indonesia \\ Medan,Indonesia \\ yunisiawira@yahoo.com \\ Silvana \\ Universitas Prima \\ Indonesia \\ Medan,Indonesia \\ silvanagoh@gmail.com
}

\author{
Lisa Octavia Liunardi \\ Universitas Prima Indonesia \\ Medan,Indonesia \\ lisaoctavia1997@yahoo.com \\ Mahmuddin Syah \\ Universitas Prima Indonesia \\ Medan,Indonesia \\ mahmuddinsyah@gmail.com
}

\section{ABSTRACT}

The automotive industry is one of a type of business that develops in the center of Indonesia. The more quantity of automotive companies is a proof, that the automotive industry has attracted many parties. This is based on the fact that Indonesia's economic power has actually been supported by our domestic side which has high purchasing power and to face the increasing public demand for transportation equipment, Indonesia car manufacturers are competing to increase the production and the quality of goods produced. This can be seen from the performance of each company. The objective of the study is to test and analyze the effect of liquidity, leverage, and activity on profitability in automotive companies listed on the Indonesia Stock Exchange in the period of 2011-2017. The research is used as a quantitive research approach. This type of research was quantitive descriptive. While the nature of research is explanatory. The research populations were automotive companies listed in the Indonesia Stock Exchange in 2011-2017 consisting of 13 companies. The research samples were 6 companies. The result of the research stated that liquidity affected the profitability in automotive companies in the Indonesia Stock Exchange in 2011-2017. Leverage affected the profitability in automotive companies in the Indonesia Stock Exchange in 2011-2017. Activity affected the rentability in automotive companies in the Indonesia Stock Exchange in 2011-2017. Simultaneously, liquidity, leverage, and activity have an effect on profitability in automotive companies in the Indonesia Stock Exchange in 2011-2017 with the coefficient of determination is $30 \%$.

Keywords: Liquidity, Leverage, Activity, Rentability 


\begin{abstract}
ABSTRAK
Industri Otomotif merupakan salah satu jenis bisnis yang berkembang di pusat Indonesia. Makin banyak kuantitas perusahaan otomotif merupakan salah satu bukti, bahwa industri otomotif telah menarik banyak pihak. Hal ini didasari oleh fakta bahwa kekuatan ekonomi Indonesia selama ini sesungguhnya ditopang oleh sisi domestik kita yang memiliki daya beli tinggi dan untuk menghadapi peningkatan permintaan masyarakat akan alat transportasi, para pabrik mobil di Indonesia berlomba-lomba untuk meningkatkan produksi dan kualitas barang yang dihasilkan. Hal ini dapat dilihat dari kinerja perusahaan masing-masing. Tujuan penelitian adalah menguji dan menganalisis pengaruh likuiditas, leverage, dan aktivitas terhadap rentabilitas pada perusahaan otomotif yang terdaftar di Bursa Efek Indonesia periode 2011-2017. Pendekatan penelitian adalah penelitian kuantitatif. Jenis penelitian yang dilakukan disini adalah deskriptif kuantitatif. Sifat penelitian ini adalah bersifat explantory. Populasi dalam penelitian ini adalah perusahaan otomotif yang terdaftar di Bursa Efek Indonesia periode 2011-2017 sebanyak 13 perusahaan. Sampel sebanyak 6 perusahaan. Hasil penelitian adalah likuditas berpengaruh terhadap rentabilitas pada perusahaan otomotif yang terdaftar di Bursa Efek Indonesia periode 2011-2017. Leverage berpengaruh terhadap rentabilitas pada perusahaan otomotif yang terdaftar di Bursa Efek Indonesia periode 20112017. Aktivitas berpengaruh terhadap rentabilitas pada perusahaan otomotif yang terdaftar di Bursa Efek Indonesia periode 2011-2017. Secara simultan likuiditas, leverage, dan aktivitas berpengaruh terhadap rentabilitas pada perusahaan otomotif yang terdaftar di Bursa Efek Indonesia periode 2011-2017 yang diketahui dari koefisien determinasi sebesar $30 \%$.
\end{abstract}

\title{
Kata kunci : Likuiditas, Leverage, Aktivitas, Rentabilitas
}

\section{Pendahuluan}

Industri Otomotif merupakan

salah satu jenis bisnis yang berkembang di pusat Indonesia. Makin banyak kuantitas perusahaan otomotif merupakan salah satu bukti, bahwa industry otomotif telah menarik banyak pihak. Hal ini didasari oleh fakta bahwa kekuatan ekonomi Indonesia selama ini sesungguhnya ditopang oleh sisi domestik kita yang memiliki daya beli tinggi dan untuk menghadapi peningkatan permintaan masyarakat akan alat transportasi, para pabrik mobil di Indonesia berlomba-lomba untuk meningkatkan produksi dan kualitas barang yang dihasilkan. Hal ini dapat dilihat dari kinerja perusahaan masing-masing.

Laba suatu perusahaan menggambarkan hasil kinerja perusahaan pada satu periode dan juga digunakan untuk menilai dan mengukur kemampuan perusahaan dalam menghasilkan keuntungan yang maksimal.

Rasio likuiditas adalah rasio yang mengukur kemampuan perusahaan dalam memenuhi kewajiban jangka pendeknya, dengan kata lain perusahaan mampu memenuhi pembayaran utang yang akan jatuh tempo. 
Rasio leverage adalah rasio yang digunakan untuk menghitung kemampuan perusahaan dalam membayar hutang jangka panjang dengan aktiva yang dimilikinya.

Rasio aktivitas adalah rasio yang digunakan untuk mengukur seberapa efektif perusahaan dalam mengendalikan seluruh aktivanya dalam mencapai keuntungan.

\section{Kajian Pustaka}

Menurut Horne \& Wachowicz (2014 : 167), rasio likuiditas adalah rasio yang mengukur kemampuan perusahaan untuk memenuhi liabilitas jangka pendeknya.

Berdasarkan pendapat yang telah dikemukan para ahli diatas, maka dapat disimpulkan bahwa likuiditas adalah kemampuan perusahaan dalam memenuhi kewajiban jangka pendeknya yang akan segera jatuh tempo.

Menurut Kodrat \& Indonanjaya (2010 : 236), rumus yang digunakan untuk mencari current ratio adalah sebagai berikut :

$$
\text { Current Ratio }=\frac{\text { Aktiva Lancar }}{\text { Utang Lancar }}
$$

Menurut Hery (2015 : 190), rasio leverage adalah rasio yang digunakan untuk mengukur sejauh mana aktiva perusahaan dibiayai dengan utang.

Berdasarkan pendapat yang telah dikemukakan para ahli diatas, maka dapat disimpulkan bahwa rasio leverage adalah menggambarkan kemampuan perusahaan dalam membayar kewajiban jangka panjang secara tepat waktu.

Menurut Kasmir (2012 : 155), rumus untuk mengukur debt to equity ratio adalah sebagai berikut :
Debt to Equity Ratio $=\frac{\text { Total Utang }}{\text { Ekuitas }}$

Menurut Raharjaputra (2011 : 199), rasio aktivitas adalah rasio yang digunakan untuk mengukur efektivitas perusahaan dalam menggunakan aktiva yang dimilikinya.

Berdasarkan pendapat yang telah dikemukakan oleh para ahli diatas, maka dapat disimpulkan bahwa rasio aktivitas digunakan untuk mengukur seberapa efektif perusahaan dalam mengendalikan seluruh aktivanya.

Menurut Kasmir (2012 : 175), rumus yang digunakan untuk mengukur inventory turn over adalah sebagai berikut :

Inventory Turn Over = Harga Pokok Penjualan

$$
\text { Persediaan }
$$

Menurut Raharjaputra (2011 : 199), rasio rentabilitas adalah rasio untuk menilai kemampuan perusahaan dalam mencari keuntungan.

Berdasarkan pendapat yang telah dikemukakan oleh para ahli diatas, maka dapat disimpulkan bahwa rasio rentabilitas adalah rasio yang mengukur kemampuan perusahaan dalam memperoleh keuntungan dengan menggunakan aset, hasil investasi ataupun kegiatan penjualan.

Menurut Hery (2015 : 228), rumus yang digunakan untuk mengukur return on assets adalah sebagai berikut :

$$
\text { Return on Assets }=\frac{\text { Laba Bersih }}{\text { Total Aset }}
$$

Berdasarkan teori yang telah diuraikan di atas, maka peneliti 
membuat kerangka konseptual yang dapat dilihat pada gambar 1 :

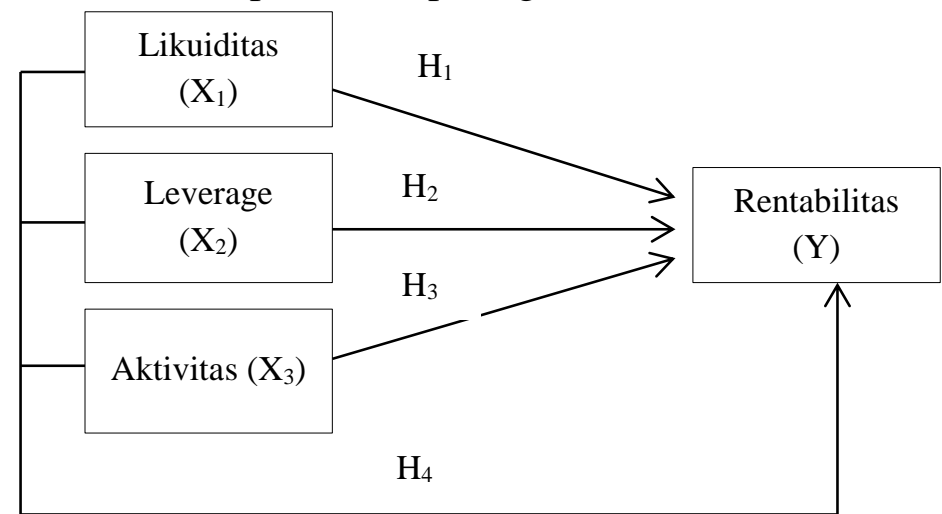

Gambar I. Kerangka Konseptual

Keterangan :

$H_{1}, H_{2}, \& H_{3}$ : Likuiditas, leverage, dan aktivitas secara parsial berpengaruh terhadap rentabilitas pada Perusahaan Otomotif yang terdaftar di Bursa Efek Indonesia periode 2011-2017.

$\mathrm{H}_{4}$ : Likuiditas, leverage dan aktivitas berpengaruh secara simultan terhadap rentabilitas pada Perusahaan Otomotif yang terdaftar di Bursa Efek Indonesia periode 2011-2017.

\section{Metode Penelitian}

Sifat penelitian yang digunakan dalam penelitian ini adalah penelitian explanatory. Menurut Sujarweni (2014: 11), tingkat eksplanasi bermaksud menjelaskan kedudukan variabel-variabel yang diteliti serta hubungan antara satu variabel dengan variabel yang lain.

\subsection{Populasi, Sampel, dan Teknik Pengumpulan Data}

Populasi dari penelitian ini adalah laporan keuangan Perusahaan
Otomotif yang terdaftar di BEI periode 2011-2017 sebanyak 13 perusahaan. Metode pengambilan sampel dalam penelitian ini menggunakan metode sampling purposive.

Teknik pengumpulan data penelitian ini adalah studi pustaka dengan mempelajari dan mengambil data dari sumber-sumber terkait yang dapat memberikan informasi mengenai penelitian ini, seperti buku teks dan jurnal ilmiah.

Jenis data penelitian ini adalah data sekunder yang diperoleh peneliti secara tidak langsung melalui media perantara (diperoleh dan dicatat oleh pihak lain).

\subsection{Variabel Penelitian}

1. Variabel dependen (Y) yang digunakan dalam penelitian ini adalah Rentabilitas.

2. Variabel independen (X) yang digunakan dalam penelitian ini adalah $\mathrm{X}_{1}$ : Likuiditas (CR) $\mathrm{X}_{2}$ : Leverage (DER) $\mathrm{X}_{3}$ : Aktivitas (ITO)

\subsection{Teknik Analisis Data}

1. Uji Asumsi Klasik

a. Uji Normalitas

Menurut Ghozali (2013 : 160164), uji normalitas bertujuan untuk menguji apakah dalam regresi, variabel penggangu atau residual memiliki distribusi normal. Ada dua cara untuk mendeteksi apakah residual berdistribusi normal atau tidak yaitu dengan analisis grafik dan uji statistik.

b. Uji Multikolinearitas 
Menurut Zainuddin, Ghodang \& Hantono (2014 : 148), uji multikolinieritas merupakan uji yang ditunjukkan untuk menguji apakah model regresi ditemukan adanya korelasi antar variabel bebas (variabel independen). Model regresi yang baik selayaknya tidak terjadi multikolinieritas.

c. Uji Autokorelasi

Menurut Ghozali (2013 : 110111),uji autokorelasi bertujuan untuk menguji apakah dalam model regresi linear ada kolerasi antara kesalahan pengganggu pada periode $\mathrm{t}$ dengan kesalahan penganggu pada periode t1 (sebelumnya). Model regresi yang baik selayaknya tidak terjadi autokorelasi.

\section{d. Uji Heterokedastisitas}

Menurut Ghozali (2013:139), uji heteroskedastisitas bertujuan untuk menguji apakah dalam model regresi terjadi ketidaksamaan variance dari residual satu pengamatan ke pengamatan yang lain. Model regresi yang baik adalah jika tidak terjadi heteroskedastisitas, atau terjadi homoskedastisitas.

\subsection{Analisis Regresi Berganda}

Persamaan regresi berganda tersebut adalah sebagai berikut :

$$
\begin{aligned}
& Y=a+b_{1} X_{1}+b_{2} X_{2}+b_{3} X_{3}+e \\
& Y \quad=\text { Rentabilitas } \\
& a \quad=\text { Konstanta } \\
& b_{1,} b_{2}, b_{3} \quad=\text { Koefisien regresi } \\
& X_{1} \quad=\text { Variabel likuiditas } \\
& X_{2} \quad=\text { Variabel leverage } \\
& X_{3} \quad=\text { Variabel aktivitas } \\
& E \quad=\text { Persentase kesalahan }
\end{aligned}
$$

\subsection{Pengujian Hipotesis}

\section{a. Uji F}

Menurut Ghozali (2013:98), uji $\mathrm{F}$ digunakan untuk menunjukkan apakah semua variabel independen atau bebas yang dimasukkan dalam model mempunyai pengaruh secara bersama-sama terhadap variabel dependen atau terikat. Uji ini dilakukan dengan membandingkan $F_{\text {hitung }}$ dengan $F_{\text {tabel }}$ dengan ketentuan sebagai berikut :

untuk $\alpha=5 \%$

$$
\mathrm{H}_{0} \text { diterima jika } \mathrm{F}_{\text {hitung }} \leq \mathrm{F}_{\text {tabel }}
$$

untuk $\alpha=5 \%$

$$
\mathrm{H}_{\mathrm{a}} \text { diterima jika } \mathrm{F}_{\text {hitung }}>\mathrm{F}_{\text {tabel }}
$$

b. Uji t

Menurut Ghozali (2013:98-99)

uji statistik $t$ digunakan untuk menunjukkan seberapa jauh pengaruh satu variabel penjelas/independen secara individual dalam menerangkan variasi variabel dependen. Uji ini dilakukan dengan membandingkan $t_{\text {hitung }}$ dengan $t_{\text {tabel }}$ dengan ketentuan sebagai berikut :

$\mathrm{H}_{0}$ diterima jika $-\mathrm{t}_{\text {tabel }} \leq \mathrm{t}_{\text {hitung }}$ $\leq t_{\text {tabel }}$ untuk $\alpha=5 \%$

$\mathrm{H}_{\mathrm{a}}$ diterima jika $t_{\text {hitung }}>\mathrm{t}_{\text {tabel }}$ atau $-\mathrm{t}_{\text {hitung }} \leq$ - $\mathrm{t}_{\text {tabel }}$ untuk $\alpha=5 \%$

c. Koefisien Determinasi

Menurut Zainuddin, Ghodang \& Hantono (2014 : 224), koefisien determinasi ditujukan untuk mengetahui seberapa besar kemampuan model dalam menerangkan variabel terikat. Jika koefisien determinasi $\left(R^{2}\right)$ semakin besar atau mendekati satu, maka dapat dikatakan bahwa kemampuan variabel bebas $(X)$ adalah besar terhadap variabel terikat $(Y)$. 


\section{Hasil dan Pembahasan}

Berdasarkan data yang diperoleh dari laporan keuangan pada periode 20112017, maka dapat dilihat daari nilai minimum, maksimum, mean, dan standar deviasi dari masing-masing variabel penelitian pada tabel 1, sebagai berikut :

\section{Tabel I. Stastistik Deskriptif}

\begin{tabular}{|l|r|r|r|r|c|}
\hline & & & & & $\begin{array}{c}\text { Std. } \\
\text { Descriptive Statistics }\end{array}$ \\
& $\mathrm{N}$ & Minimum & Maximum & Mean & Deviation \\
\hline $\mathrm{CR}$ & 42 & 1,05 & 5,13 & 1,9359 & 0,88447 \\
DER & 42 & 0,14 & 2,38 & 0,7175 & 0,46187 \\
ITO & 42 & 2,24 & 10,99 & 4,9657 & 2,30396 \\
ROA & 42 & 0,001 & 0,24 & 0,0886 & 0,06569 \\
Valid N & 42 & & & & \\
(listwise) & & & & & \\
\hline
\end{tabular}

Berdasarkan hasil perhitungan tabel 1, terdapat 42 sampel. Nilai ratarata current ratio adalah sebesar 1,9359 dengan standar deviasinya adalah 0,88447 . Nilai rata-rata debt to equity ratio adalah sebesar 0,7175 dengan standar deviasinya adalah 0,46187 . Nilai rata-rata inventory turn over adalah sebesar 4,9657 dengann standar deviasinya adalah 2,30396. Nilai rata-rata return on asstes adalah sebesar 0,0886 dengan standar deviasinya adalah 0,06569 .

Uji asumsi klasik merupakan suatu persyaratan statistik yang harus dipenuhi untuk melakukan analisis regresi linear, hal ini bertujuan untuk mengetahui apakah data yang diteliti telah memenuhi sebuah kelayakan dalam penelitian.
Uji normalitas bertujuan untuk mengetahui data yang digunakan dalam penelitian ini terdapat distribusi normal atau terjadi pelanggaran asumsi yang mengakibatkan data menjadi tidak valid. Dalam penelitian ini, peneliti menggunakan 2 uji untuk mendeteksi apakah data yang digunakan berdistribusi normal atau tidak, yaitu uji analisis grafik dan uji statistik. Hasil pengujian normalitas dapat dilihat dari gambar 2 dibawah ini :

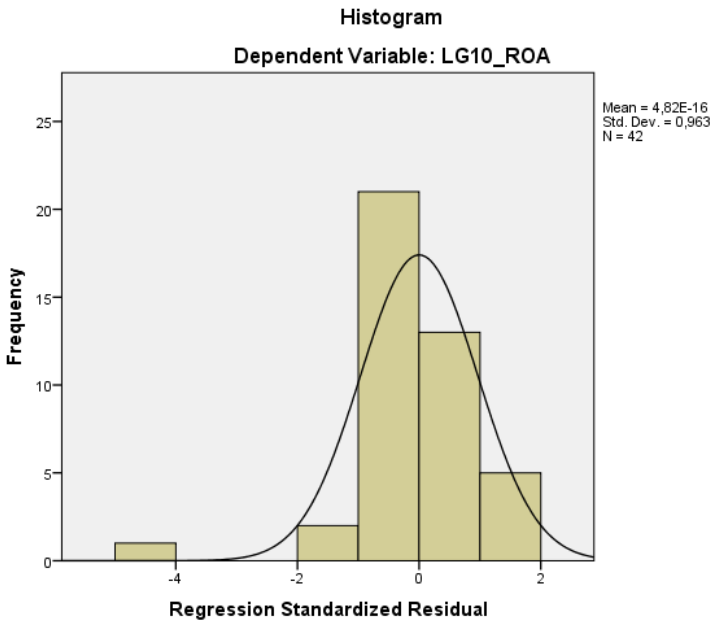

\section{Gambar 2. Hasil Pengujian Normalitas Histogram}

Dari hasil pengamatan pada gambar 2 di atas, menunjukkan bahwa kurva terdistribusi dengan pola yang normal, simetris, tidak terjadi skrewness ke kiri atau ke kanan, maka dapat dikatakan data yang diteliti dalam model regresi memenuhi syarat asumsi normalitas. 


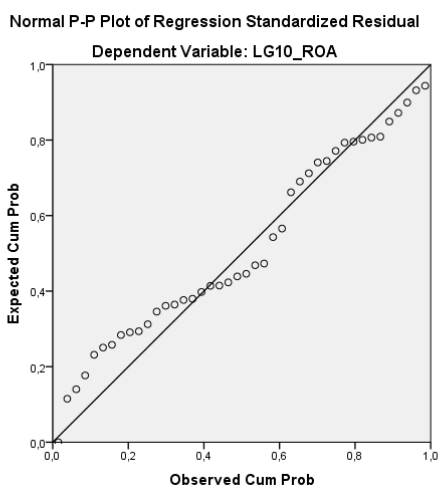

Gambar 3. Hasil Pengujian

Normalitas Data P-P Plot

Dari gambar 3 di atas, menunjukkan penyebaran titik-titik yang menyebar di garis diagonal serta mengikuti arah garis diagonal, maka dalam model regresi penelitian ini telah sesuai memiliki kriteria asumsi normalitas.

Tabel 2. Hasil Pengujian Normalitas Kolmogrov-Smirnov

One-Sample Kolmogorov-Smirnov Test

\begin{tabular}{|ll|r|}
\hline & & $\begin{array}{r}\text { Unstandardized } \\
\text { Residual }\end{array}$ \\
\hline $\mathrm{N}$ & Mean & 0,0000000 \\
Normal & Std. & 0,35364623 \\
Parameters $^{\mathrm{a}, \mathrm{b}}$ & Deviation & 0,128 \\
Most & Absolute & 0,099 \\
Extreme & Positive & $-0,128$ \\
Differences & Negative & 0,128 \\
Test Statistic & & $0,083^{\mathrm{c}}$ \\
Asymp. Sig. (2-tailed) &
\end{tabular}

a. Test distribution is Normal.

b. Calculated from data.

c. Lilliefors Significance Correction.

Pada tabel 2, hasil $K$-S adalah 0,128 dengan asym. Sig. (2-tailed) berada pada angka 0,083 yang artinya melebihi tingkat signifikansi 0,05 . Hal ini berarati $H_{a}$ ditolak dan $H_{0}$ diterima yang menyatakan data residual berdistribusi normal.

Hasil pengujian multikolinearitas dalam penelitian ini adalah sebagai berikut :

Tabel 3. Hasil Pengujian Multikolinearitas

\section{Coefficients $^{\mathrm{a}}$}

\begin{tabular}{|l|r|r|}
\hline \multirow{2}{*}{ Model } & \multicolumn{2}{|c|}{$\begin{array}{c}\text { Collinearity } \\
\text { Statistics }\end{array}$} \\
\cline { 2 - 4 } & Tolerance & VIF \\
\hline 1 (Constant) & & \\
LG10_CR & 0,308 & 3,250 \\
LG10_DER & 0,362 & 2,760 \\
LG10_ITO & 0,768 & 1,303 \\
\hline
\end{tabular}

a. Dependent Variable: LG10_ROA

Berdasarkan tabel 3 di atas, diketahui bahwa tidak ada variabel independen yang memiliki nilai tolerance kurang dari 0,10 dan tidak ada variabel independen yang memiliki nilai variance inflation factor (VIF) yang melebihi nilai 10 . Jadi dapat disimpulkan bahwa tidak terjadinya multikolinieritas antar variabel bebas dalam regresi.

Hasil pengujian autokorelasi dalam penelitian ini adalah sebagai berikut :

\section{Tabel 4. Hasil Pengujian} Autokorelasi 
Model Summary ${ }^{b}$

\begin{tabular}{|l|c|r|r|r|r|}
\hline Model & $\mathrm{R}$ & $\begin{array}{c}\mathrm{R} \\
\text { Square }\end{array}$ & $\begin{array}{c}\text { Adjusted } \\
\text { R Square }\end{array}$ & $\begin{array}{c}\text { Std. Error of } \\
\text { the Estimate }\end{array}$ & $\begin{array}{c}\text { Durbin- } \\
\text { Watson }\end{array}$ \\
\hline 1 &, $548^{\mathrm{a}}$ &, 300 &, 245 &, 36734 & 2,173 \\
\hline
\end{tabular}

a. Predictors: (Constant), LG10_ITO, LG10_DER, LG10_CR

b. Dependent Variable: LG10_ROA

Berdarsarkan tabel 4 di atas menunjukkan nilai Durbin-Watson sebesar 2,173. Nilai dl sebesar 1,3573 dan nilai du sebesar 1,6617 dengan nilai sampel $(n)$ sebanyak 42 dari variabel independen sebanyak $3(\mathrm{k})$. Hal ini dapat diketahui dengan keputusan uji Durbin-Watson bahwa syarat tidak terjadinya autokorelasi adalah du < d < 4-du, yaitu 1,6617 < $2,173<2,3383$, jadi disimpulkan bahwa $H_{0}$ diterima yaitu tidak ada autokorelasi dalam model regresi penelitian ini dan $\mathrm{Ha}$ ditolak.

\section{Hasil}

heterokedastisitas

pengujian menggunakan analisis grafik dapat dilihat dari grafik scatterplot berikut ini :

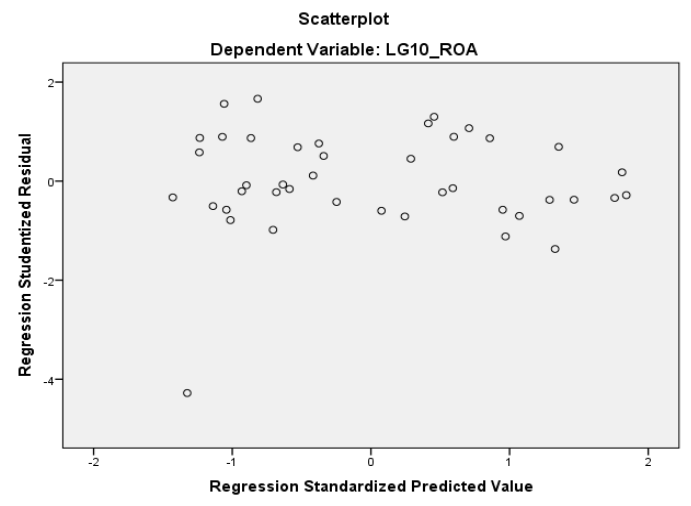

Gambar 4. Hasil Pengujian Grafik Scatterplot
Berdasarkan data pada gambar 4 di atas, menunjukkan penyebaran titiktitik yang secara acak baik diatas maupun dibawah angka nol (0) pada sumbu $Y$, hal ini dapat diindikasikan bahwa tidak terjadi heteroskedastisitas dalam model regresi penelitian ini. Untuk mempertegas hasil maka peneliti melakukan uji glejser, berikut hasil ujinya :

\section{Tabel 5. Hasil Pengujian Glejser}

\section{Coefficients $^{\mathrm{a}}$}

\begin{tabular}{|c|c|c|c|c|c|}
\hline \multirow[b]{2}{*}{ Model } & \multicolumn{2}{|c|}{$\begin{array}{l}\text { Unstandardize } \\
\text { d Coefficients }\end{array}$} & $\begin{array}{c}\text { Standardize } \\
\text { d } \\
\text { Coefficients }\end{array}$ & & \\
\hline & B & $\begin{array}{l}\text { Std. } \\
\text { Error }\end{array}$ & Beta & $\mathrm{t}$ & Sig. \\
\hline 1 (Constant) & 0,453 & 0,197 & & 2,305 & 0,027 \\
\hline LG10_CR & $\begin{array}{r}- \\
0,252\end{array}$ & 0,381 & $-0,181$ & $-0,663$ & 0,511 \\
\hline $\begin{array}{l}\text { LG10_DE } \\
\mathrm{R}\end{array}$ & $\begin{array}{r}- \\
0,346\end{array}$ & 0,229 & $-0,381$ & $-1,515$ & 0,138 \\
\hline $\begin{array}{l}\text { LG10_IT } \\
\text { O }\end{array}$ & $\begin{array}{r}- \\
0,324\end{array}$ & 0,235 & $-0,238$ & $-1,379$ & 0,176 \\
\hline
\end{tabular}

a. Dependent Variable: ABS_RES1

Berdasarkan tabel 5 di atas dapat disimpulkan bahwa variable current ratio $(\mathrm{CR})$, debt to equity ratio (DER) dan inventory turn over (ITO) memiliki nilai diatas tingkat signifikansi 0,05. Dalam hal ini dapat dikatakan bahwa dalam model regresi penelitian ini tidak terdapat masalah heteroskedastisitas.

Pengujian hipotesis yang digunakan dalam penelitian adalah dengan menggunakan analisis linear 
berganda. Model regresi yang digunakan adalah sebagai berikut :
Tabel 6. Hasil Pengujian Regresi Linear Berganda

\begin{tabular}{|l|r|r|c|}
\hline \multirow{2}{*}{} & \multicolumn{2}{|c|}{ Coefficients $^{\mathbf{a}}$} \\
& \multicolumn{2}{|c|}{$\begin{array}{c}\text { Unstandardized } \\
\text { Coefficients }\end{array}$} & $\begin{array}{c}\text { Standardized } \\
\text { Coefficients }\end{array}$ \\
\cline { 2 - 5 } Model & B & \multicolumn{1}{c|}{$\begin{array}{c}\text { Std. } \\
\text { Error }\end{array}$} & \multicolumn{1}{c|}{ Beta } \\
\hline 1 (Constant) & - & 0,307 & \\
& 2,255 & & \\
LG10_CR & 2,161 & 0,595 & 0,889 \\
LG10_DER & 1,039 & 0,358 & 0,656 \\
LG10_ITO & 1,143 & 0,367 & 0,482 \\
\hline
\end{tabular}

a. Dependent Variable: LG10_ROA

Melalui data Tabel IV.11 diatas pada kolom unstandardized coefficients pada bagian $\mathrm{B}$, maka diperoleh persamaan regresi linear berganda adalah sebagai berikut:

$L G 10 \_R O A=-2,255+2,161$

LG10_CR + 1,039LG10_DER +

$$
\text { 1,143 LG10_ITO +e }
$$

Koefisien determinasi adjusted $R$ square untuk mengukur seberapa jauh kemampuan model dalam menerangkan variasi variabel independen. Hasil perhitungan dapat dilihat dari tabel 7 di bawah ini :

\begin{tabular}{|c|c|c|c|c|c|}
\hline $\begin{array}{l}\text { Mod } \\
\text { el }\end{array}$ & $\mathrm{R}$ & $\begin{array}{c}\mathrm{R} \\
\text { Squa } \\
\text { re }\end{array}$ & $\begin{array}{c}\text { Adjust } \\
\text { ed R } \\
\text { Squar } \\
\text { e }\end{array}$ & $\begin{array}{l}\text { Std. } \\
\text { Error } \\
\text { of the } \\
\text { Estim } \\
\text { ate }\end{array}$ & \begin{tabular}{|c} 
Durbi \\
n- \\
Wats \\
on
\end{tabular} \\
\hline 1 & $\begin{array}{r}0,54 \\
8^{\mathrm{a}}\end{array}$ & $\begin{array}{r}0,30 \\
0\end{array}$ & 0,245 & $\begin{array}{r}0,367 \\
34\end{array}$ & 2,173 \\
\hline
\end{tabular}

a. Predictors: (Constant), LG10_ITO,

LG10_DER, LG10_CR

b. Dependent Variable: LG10_ROA

Berdasarkan data tabel 7 di atas, menunjukkan bahwa nilai $\mathrm{R}^{2}$ yang diperoleh adalah 0,300. Artinya 30\% return on assets (ROA) sebagai variabel terikat dapat dijelaskan oleh variasi dari variabel bebas yaitu current ratio (CR), debt to equity ratio (DER) dan inventory turn over (ITO). Sedangkan $70 \%$ dapat dijelaskan oleh faktor lainnya yang tidak diteliti diluar model penelitian ini, contohnya seperti variabel perputaran kas, aktiva tetap, cash ratio, debt to asset ratio dan sebagainya.

Uji $\mathrm{F}$ digunakan untuk menunjukkan bahwa apakah semua variabel bebas current ratio (CR), debt to equity ratio (DER) dan inventory turn over (ITO) secara simultan atau bersama-sama dapat memengaruhi variabel terikat return on assets (ROA). Berikut adalah hasil uji $\mathrm{F}$ :

Tabel 8. Hasil Pengujian Statistik Uji F

\begin{tabular}{|c|c|c|c|c|c|c|}
\hline \multirow[b]{2}{*}{$\begin{array}{c}\text { Tabel 7. Hasil Pengujian Koef } \\
\text { Determinasi Hipotesis }\end{array}$} & \multicolumn{6}{|c|}{ ANOVA $^{\mathrm{a}}$} \\
\hline & Model & $\begin{array}{l}\text { Sum of } \\
\text { Squares }\end{array}$ & $\mathrm{df}$ & $\begin{array}{c}\text { Mean } \\
\text { Square }\end{array}$ & $\mathrm{F}$ & Sig. \\
\hline Model Summary ${ }^{b}$ & 1 Regression & 2,199 & 3 &, 733 & 5,432 &, $003^{\mathrm{b}}$ \\
\hline & Residual & 5,128 & 38 &, 135 & & \\
\hline
\end{tabular}




\section{$\frac{\text { Total }}{\text { a. Dependent }}$
b. Predictors:
LG10_CR}

Pada hasil pengujian tabel 8 , dapat diketahui nilai $F_{\text {hitung }}$ menunjukkan angka sebesar 5,432 dengan nilai signifikansi sebesar 0,003 . Berdasarkan ketentuan yang terdapat bahwa nilai $F_{\text {hitung }}>F_{\text {tabel }}$ dan dimana nilai $F_{\text {tabel }}$ dengan jumlah pembilang $\left(d f_{l}\right)$ sebesar 3 serta jumlah untuk penyebut $\left(d f_{2}\right)$ adalah 38 dengan hasil $F_{\text {tabel }}$ adalah 2,85, maka hasil dari statistik uji $F_{\text {hitung }}>F_{\text {tabel }}(5,432>$ $2,85)$ menunjukkan variabel current ratio (CR), debt to equity ratio (DER) dan inventory turn over (ITO) berpengaruh signifikan terhadap return on assets (ROA). Hal ini berarti hipotesis $H_{0}$ ditolak dan $H_{a}$ diterima yang artinya current ratio (CR), debt to equity ratio (DER) dan inventory turn over (ITO) secara simultan berpengaruh signifikan terhadap return on assets (ROA) pada Perusahaan Otomitif Di Bursa Efek Indonesia periode 2011-2017.

Uji $\mathrm{t}$ memiliki tujuan untuk mengetahui apakah terdapat pengaruh variabel bebas terhadap variabel terikat secara individual. Berikut tabel yang disajikan mengenai hasil uji $t$ :

Tabel 9. Hasil Pengujian Statistik Uji $t$

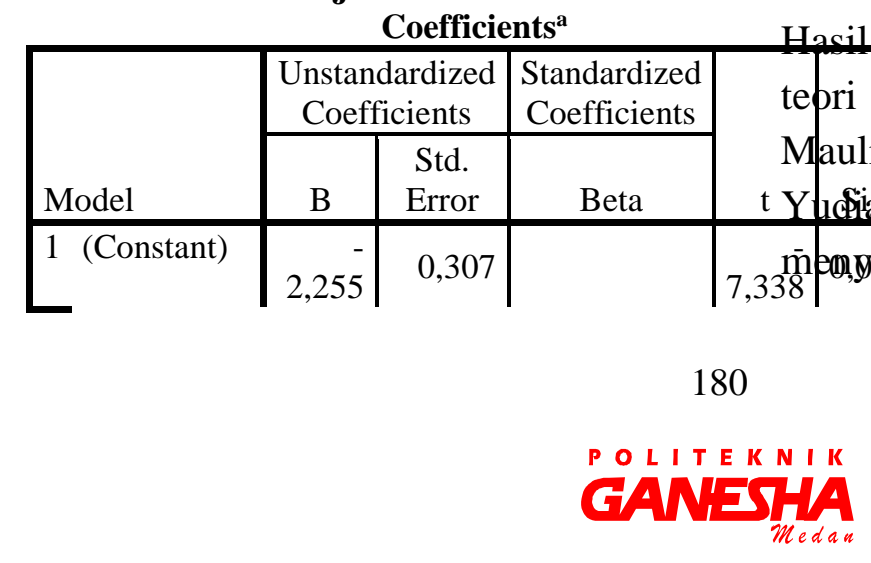

\begin{tabular}{l|l|l|l|l|l|}
\hline LG10_CR & 2,161 & 0,595 & 0,889 & 3,632 & 0,001 \\
LG10_DER & 1,039 & 0,358 & 0,656 & 2,907 & 0,006 \\
LG10_ITO & 1,143 & 0,367 & 0,482 & 3,112 & 0,004 \\
\hline
\end{tabular}

a. Dependent Variable: LG10_ROA

Hasil pengujian uji $t$ secara parsial diperoleh thitung untuk variabel current ratio (CR) adalah sebesar 3,632 dengan signifikansi sebesar 0,001 . Nilai $t_{\text {hitung }}>t_{\text {tabel }}$ atau 3,632 > 2,02439 maka $H_{0}$ ditolak dan $H_{a}$ diterima artinya current ratio (CR) secara parsial berpengaruh positif signifikan terhadap return on assets (ROA) Hasil penelitian ini sejalan dengan teori menurut Jumhana Cheppy Safei (2017) yang menyatakan bahwa likuiditas berpengaruh positif terhadap profitabilitas dan teori menurut Rahmah Amrita Maulidia, Wayan Cipta \& Fridayana Yudiaatmaja (2016) yang menyatakan bahwa secara parsial likuiditas berpengaruh positif terhadap profitabilitas.

Hasil pengujian uji $t$ secara parsial diperoleh thitung untuk variabel debt to equity ratio (DER) adalah sebesar 2,907 dengan signifikansi sebesar 0,006. Nilai $t_{\text {hitung }}>t_{\text {tabel }}$ atau 2,907 > 2,02439 maka $H_{0}$ ditolak dan $H_{a}$ diterima artinya debt to equity ratio (DER) secara parsial berpengaruh positif signifikan terhadap return on assets (ROA) Hacil penelitian ini sejalan dengan teori menurut Rahmah Amrita Maulidia, Wayan Cipta \& Fridayana Yusisatmaja (2016) yang bahwa leverage 
berpengaruh signifikan postif terhadap profitabilitas. Sedangkan hasil penelitian ini bertentangan dengan teori Putra Wela Yulia \& Ida Bagus Badjra (2015) yang menyatakan bahwa leverage berpengaruh negatif dan signifikan terhadap profitabilitas.

Hasil pengujian uji $t$ secara parsial diperoleh thitung untuk variabel inventory turn over (ITO) adalah sebesar 3,112 dengan signifikansi sebesar $\quad 0,004$ Nilai $t_{\text {hitung }}>t_{\text {tabel }}$ atau $3,112>2,02439$ maka $H_{0}$ ditolak dan $H_{a}$ diterima artinya inventory turn over (ITO) secara parsial berpengaruh positif signifikan terhadap return on assets (ROA) Hasil penelitian ini sejalan dengan teori Jumhana Cheppy Safei (2017) yang menyatakan bahwa aktivatas berpengaruh signifikan terhadap profitabilitas dan teori menurut Rahmah Amrita Maulidia, Wayan Cipta \& Fridayana Yudiaatmaja (2016) yang menyatakan bahwa aktivitas berpengaruh positif dan signifikan secara parsial terhadap profitabilitas.

\section{KESIMPULAN}

\section{Kesimpulan}

Secara parsial current ratio (CR) berpengaruh signifikan posotif terhadap return on asset (ROA) pada Perusahaan Otomotif yang terdaftar di Bursa Efek Indonesia periode 2011-2017 dengan $t_{\text {hitung }}>t_{\text {tabel }}$ atau
3,632 > 2,02439 dan signifikan 0,001. Secara parsial debt to equity ratio (DER) berpengaruh signifikan positif terhadap return on asset (ROA) pada Perusahaan Otomotif yang terdaftar di Bursa Efek Indonesia periode 2011-2017 dengan $t_{\text {hitung }}>t_{\text {tabel }}$ atau $2,907>2,02439$ dan signifikansi 0,006 . Secara parsial inventory turn over (ITO) berpengaruh signifikan positif terhadap return on asset (ROA) pada Perusahaan Otomotif yang terdaftar di Bursa Efek Indonesia periode 2011-2017 dengan thitung > $t_{\text {tabel }}$ atau 3,112>2,02439 dan signifikansi 0,004. Secara simultan current ratio (CR), debt to equity ratio (DER) dan inventory turn over (IVO) berpengaruh signifikan terhadap return on asset (ROA) pada Perusahaan Otomotif yang terdaftar di Bursa Efek Indonesia periode 2011-2017 dengan $F_{\text {hitung }}>F_{\text {tabel }}$ $(5,432>2,85)$ dan signifikansi 0,003 . Koefisien determinasi yang dihasilkan adalah sebesar $30 \%$ artinya variabel bebas yaitu current ratio (CR), debt to equity ratio (DER) dan inventory turn over (ITO) berhasil menjelaskan sebesar 30\% terhadap return on asset (ROA). Sedangkan sisanya sebesar $70 \%$ dapat dijelaskan oleh faktor lainnya yang tidak diteliti diluar model penelitian ini, contohnya variabel perputaran kas, aktiva tetap, cash ratio, debt to asset ratio dan sebagainya.

\section{DAFTAR PUSTAKA}

Fahmi, Irham. 2012. Analisis Kinerja Keuangan. Cetakan Kesatu. Bandung: CV Alfabeta.

2013. Analisis Laporan Keuangan. Cetakan 
Ketiga, Bandung: CV Alfabeta.

2014. Manajemen

Keuangan Perusahaan Dan

Pasar Modal. Ed.1, Jakarta:

Mitra Wacana Media.

Ghozali, Imam. 2013. Aplikasi Analisis Multivariate dengan Program IBM. Ed. 7, Jakarta: Universitas Diponegoro.

Harahap, Sofyan Syafri. 2013. Manajemen Keuangan Teori dan Aplikasi. Cetakan Kesebelas. Jakarta: PT Raja Grafindo Persada.

Harmono. 2015. Manajemen Keuangan. Ed.1, Cetakan Keempat. Jakarta: Bumi Aksara.

Hery. 2015. Analisis Laporan Keuangan Pendekatan Rasio Keuangan. Cetakan Kesatu. Yogyakarta: CAPS.

Horne, James C. Van \& John M. Wachowicz. 2014. PrinsipPrinsip Manajemen Keuangan Fundamentals of Financial Management. Ed. 13, Buku 1. Jakarta: Salemba Empat.

Jumhana, R Cheppy Safei. (2017). Pengaruh Rasio Likuiditas dan Rasio Aktivitas Terhadap Profitabilitas pada Koperasi Karyawan PT Surya Toto Indonesia. Jurnal Sekuritas, Desember (1), 54-73.
Kasmir. 2012. Analisis Laporan Keuangan. Cetakan Kelima. Jakarta: PT Raja Grafindo Persada.

Kodrat, David Sukardi \& Kurniawan Indonanjaya. 2010. Manajemen Investasi Pendekatan Teknikal dan Fundamental untuk Analisis Saham. Ed. 1, Cetakan Kesatu. Yogyakarta: Graha Ilmu.

Kridasusila, Andi \& Windasari Rachmawati. (2016). Analisis Pengaruh Current Ratio, Inventory Turn Over dan Debt To Equity Ratio Pada Perusahaan Otomotif dan Produk Komponennya Pada Bursa Efek Indonesia (20102013). Jurnal Dinamika Sosila Budaya, Juni (81), 722.

Putra, A.A Wela Yulia. (2015). Pengaruh Leverage, Pertumbuhan Penjualan dan Ukuran Perusahaan Terhadap Profitabilitas. Jurnal Manajemen, (4).

Raharjaputra, Hendra. 2011. Buku Panduan Praktis Manajemen Keuangan dan Akuntansi untuk Eksekutif Perusahaan. Cetakan Kesatu. Jakarta Selatan: Salemba Empat.

Rahmah, Amrita Maulidia, Wayan Cipta \& Fridayana Yudiaatmaja. (2016). Pengaruh Likuiditas, Solvabilitas dan Aktivitas 
Terhadap Profitabilitas pada Perusahaan Otomotig yang Terdaftar di Bursa Efek Indonesia Periode 2012-2014. Jurnal Manajemen, (4).

Sartono, R. Agus. 2012. Manajemen Keuangan Teori dan Aplikasi. Cetakan Keenam. Yogyakarta: BPFE Yogyakarta.

Sjahrial, Dermawan. 2012. Pengantar Manajemen Keuangan. Ed. 4, Jakarta: Mitra Wacana Media.

Sunyoto, Danang. 2011. Metodologi Penelitian Untuk Ekonomi. Cetakan Pertama, Yogyakarta: CAPS.

Subramanyam, K.R \& John J. Wild. 2013. Analisis Laporan Keuangan. Jakarta: Salemba Empat.

Sujarweni, V. Wiratna. 2014. Metodologi Penelitian. Yogyakerta: Pustaka Baru Press.

Zainuddin, Hironymus Ghodang \& Hantono. 2014. Konsep Dasar dan Aplikasi Statistik Pendekatan SPSS. Cetakan Kesatu. Yogyakarta: Citra Pustaka Media. 